\title{
Comparative Antioxidant Effects of Two Separate Ethanolic Extracts Fed Female Albino Rats on Some Tissue Markers
}

\author{
Oladimeji S.O.* Yusuf A. Abdurrahman O. H. Oseni Z.O. \\ Department of Biochemistry, Lagos State University, Ojo.
}

\begin{abstract}
Garcinia kola and Curcuma longa possess antioxidant, anti-inflammatory and anti-toxic properties which makes them ideal choices in traditional alternative medicine. Kolaviron and curcumin ethanoic extracts are from Garcinia kola and Curcuma longa respectively and have shown ample beneficial health effect in animal models of diseases and also in the prevention of hepatoxicity induced by several toxins. The aim of the study was to compare the separate effects of kolaviron and curcumin ethanoic extracts on blood parameters in female Wister albino rats.

Eighty-four female albino rats were used in this study and were grouped into fertile, infertile and pregnant rats in the investigation. Anti-oxidant markers such as catalase, superoxide dismutase (SOD), glutathione s-transferase (GST) were assayed for in this study.The result shows that both kolaviron and curcumin, possess antioxidant properties and the results from the three groups investigated, showed that the extracts had similar influence (antioxidants effect) on pregnancy, as kolaviron showed a bit more "potency". In the infertile rats, both extracts present competing anti-oxidants effects on the organs. In conclusion, kolaviron presented a more effective anti-oxidants property across the three subject groups studied compared to curcumin.
\end{abstract}

Keywords: Garcinia Kola, Turmeric, Kolaviron, Curcumin, Haematological, antioxidants Parameters

DOI: $10.7176 / \mathrm{JNSR} / 13-6-04$

Publication date:March $31^{\text {st }} 2021$

\section{INTRODUCTION}

Garcinia Kola is widely used in traditional medicine in Africa with most parts of the plant being used and a wide range of ailments being treated, from which several medically active compounds have been identified, (HernandezReif et al., 2019). Tannins, a reducing sugar and traces of an alkaloid have been detected in the bark, flavonins are also present, while the whole plant being, extremely bitter, resinous and astringent. A number of pharmacological actions have also been demonstrated, as the fruits, seeds, nuts, and bark of the plant have been used for centuries in folk medicine to treat ailments from cough to fever (Priyadarsini, 2014).

Extracts of stems, roots and seeds (kolaviron) have been shown to have strong anti-hepatotoxic and hepatotropic activity. Petroleum ether and acetone extracts were found to be markedly anti-microbial (Farombi et al., 2002, 2013). The seeds are said to be an antidote, antitussive, aphrodisiac, astringent and vermifuge. Mastication of the seeds is said to relieve coughs, hoarseness, and bronchial and throat troubles. They are taken dry as a remedy for dysentery. They are said to provide an antidote against Strophanthus poisoning. The active principle, or principles, in the nut remains enigmatic. Caffeine which is present in the true kola is absent, a trace of alkaloid has been reported in Nigerian materials, but absent in other samples (Farombi et al., 2002).

Turmeric (Curcuma longa) belongs to the family Zingiberaceae includes more than 80 species of rhizomatous perennial herbs and has widespread existence in the tropics of Asia, Africa, and Australia, (Priyadarsini, 2014). C. longa, commonly known as turmeric (Haldi), is a well-known plant which is used as a drug in Ayurvedic and Unani system of medicine (Stohs and Ray, 2019). The World Health Organization has suggested the use of turmeric as a spice, (Srivastava et al., 2016). Comprehensively, Curcuma attainment is importance as a growing source of new drug(s) to fight a variety of ailments as the species contain molecules validated with anti-fungal properties (Hernandez-Reif et al., 2019), anti-inflammatory, hepatoprotective, antitumor, antiviral, (Ammon et al., 1991) and anticancer activities (Stohs, and Ray, 2019). Curcumin (diferuloylmethane) is a natural yellow polyphenolic pigment isolated from the rhizomes of the plant Curcuma longa, (Owaga et al., 2014). It is commonly used as a food additive and it shows a wide spectrum of biological and pharmacological effects, such as antiinflammatory, antioxidant, antimicrobial, anti-hepatoxic, hypolipidemic, and anticancer properties (Srivastava et al., 2016). Curcumin also has immunomodulatory and anti-allergic activities (Owaga et al., 2014).

\section{METHODS}

Collection of Plant materials and Authentication

Garcinia kola and fresh roots of Curcuma longa were used in this study. The Garcinia kola was obtained from a local farm in Osun state, Nigeria. While the roots of the Curcuma longa were procured from a local farm in Kaduna, Nigeria. Authentication for both plant samples was carried out at the Herbarium unit of Botany department, University of Lagos. 
Extraction of Curcumin and Kolaviron

The outer coats of the Curcuma longa and Garcinia kola were removed and the seeds and roots respectively were cut into small pieces, washed and air dried. The dried seeds (roots) were grounded to fine powder and extraction was done separately, using 70\% ethanol in a Soxhlet extractor. The yield was concentrated by evaporation in a rotary evaporator and dried solid was obtained.

\section{Collection and Acclimatization of Animals}

Female albino rats weighing between $70-100 \mathrm{~g}$ were obtained from the animal house of the Department of Biochemistry, University of Ibadan, Oyo state. The rats were kept in wire meshed cages for two weeks to acclimatize. The animals were fed with commercial rat feed. The rats that were selected for administration of extracts weighed between $130 \mathrm{~g}-150 \mathrm{~g}$ having an average weight of $140 \mathrm{~g}$.

\section{Chronic Toxicity Test}

Chronic toxicity test was performed on the animals to determine the actual dose to be administered to avoid high rate of deaths in the groups. In summary, a total of eighteen (18) rats were selected at random and observed for the toxicity test, nine (9) for kolaviron in a three (3) rats per cage grouping, and nine (9) for curcumin in another three (3) rats per cage grouping, making up six (6) cages, each cage received different doses of plant extract.

The doses administered for the toxicity test for Kolaviron: $400 \mathrm{mg} / \mathrm{kg}$ for cage $1,600 \mathrm{mg} / \mathrm{kg}$ for cage 2 , and $800 \mathrm{mg} / \mathrm{kg}$ for cage 3

The doses administered for the toxicity test for Curcumin: $400 \mathrm{mg} / \mathrm{kg}$ for cage $1,500 \mathrm{mg} / \mathrm{kg}$ for cage 2 , and $600 \mathrm{mg} / \mathrm{kg}$ for cage 3 .

\section{Animal Groupings}

In order to know the actual dose to be administered to each animal in the group, calculation was done according to the average body weight before administration. All animals in the groups were repeatedly administered by oral gavages to the respective dose of kolaviron for 14 days. Concentrated kolaviron was dissolved in corn oil while curcumin was dissolved in olive oil.

Group 1 served as the control and the other test group that received administrations with oral gavage. Prior to treatment of, rats in groups 2, 5, 6, 7 and 8, that were made infertile with postinor-2. Rats in group 2 continued using the postinor-2, three days interval throughout the experimental period. Also, rats in groups 9,10 and 11 were mated and were made pregnant with male rats procured along with the female at the beginning. GROUPS

\begin{tabular}{lllc}
1 & Control (Distilled Water), 2 & \multicolumn{1}{c}{ Infertile Group, 3} & Kolaviron only $(200 \mathrm{mg} / \mathrm{kg})$ \\
4 & Curcumin only $(100 \mathrm{mg} / \mathrm{kg}), 5$ & Low-Dose Kolaviron $(200 \mathrm{mg} / \mathrm{kg})$ \\
6 & High-Dose Kolaviron $(400 \mathrm{mg} / \mathrm{kg}), 7$ & Low-dose Curcumin $(100 \mathrm{mg} / \mathrm{kg})$ \\
8 & High-dose Curcumin $(400 \mathrm{mg} / \mathrm{kg}), 9$ & Pregnant Group, \\
10 & Pregnancy+ Kolaviron $(200 \mathrm{mg} / \mathrm{kg}), 11$ & Pregnancy+ Curcumin $(100 \mathrm{mg} / \mathrm{kg})$
\end{tabular}

\section{Extraction/collection of blood samples and storage}

After fourteen days of treatment, the rats were then anaesthetized using diethyl-ether and were sacrificed followed by the collection of blood samples and extraction of organs. Blood samples were collected by cardiac puncture, into well labeled EDTA and plain bottles, then stored frozen in a refrigerator until ready for use. The kidney, liver and ovary of each of the rats were extracted immediately after blood collection. The organs were preserved in phosphate buffer ( $\mathrm{pH}$ 7.4) before being homogenized. After homogenization, the homogenate were then centrifuged at $3000 \mathrm{rpm}$. The supernatants were decanted in well labeled plain bottles and then stored in a refrigerator until ready for use.

\section{Determination of anti-inflammatory markers Determination of superoxide dismutase (SOD) activity}

The percentage inhibition of SOD was determined using the method of José, et al., (2013). The increase in absorbance at $480 \mathrm{~nm}$ was monitored every 30 seconds for 150 seconds.

\section{Determination of catalase activity}

Catalase activity was determined according to the method of Odewabi et al., (2014). The changed in the colour of the solution to stable green due to formation of chromic acetate. After cooling at room temperature, the volume of the reaction mixture was made to $3 \mathrm{ml}$ and the optical density measured with a spectrophotometer at $570 \mathrm{~nm}$.

\section{Estimation of glutathione S-transferase activity}

Glutathione S-transferase activity was determined according to the method of Pérez - Chaca et al., (2014). The 
medium for the estimation was prepared and the reaction was allowed to run for 60 seconds each time before the absorbance was read against the blank at $340 \mathrm{~nm}$. The temperature was maintained at approximately $31{ }^{\circ} \mathrm{C}$.

\section{Statistical Analysis}

All statistical analysis was performed using Graph pad prism 5 (statistical software). The results were first expressed as mean \pm standard errors of mean (SEM) with a $95 \%$ confidence interval for mean. The data were then analyzed using one-way analysis of variance (ANOVA) followed by comparison using Tukey's Honest Significant Difference (HSD) post-hoc test. Values of $\mathrm{P}<0.05$ were considered statistically significant.

The data were then analyzed using two-way analysis of variance (ANOVA) followed by comparison between the two extracts using Bonferroni post-hoc test.

\section{RESULTS}

Table 1: Results showing the amount of phytochemicals (quantitative) present in Garcinia kola and Curcuma longa

\begin{tabular}{|l|l|l|}
\hline phytochemical & Garcinia kola $(\mathrm{mg} / \mathrm{g})$ & Curcuma longa $(\mathrm{mg} / \mathrm{g})$ \\
\hline Phenols & 0.23 & 21.27 \\
\hline Alkaloids & 0.72 & 8.54 \\
\hline Tannins & 0.26 & 42.49 \\
\hline Saponins & 9.41 & 11.06 \\
\hline Flavonoids & 1.04 & 57.80 \\
\hline
\end{tabular}

The result of the chronic toxicity test performed. on the animals to determine the actual dose to be administered to avoid high rate of deaths in the groups, showed that no death was recorded during the toxicity test. The result in figure 1 shows data obtained for the SOD activities in the kidney of all the groups treatment compared for the two extracts administered.

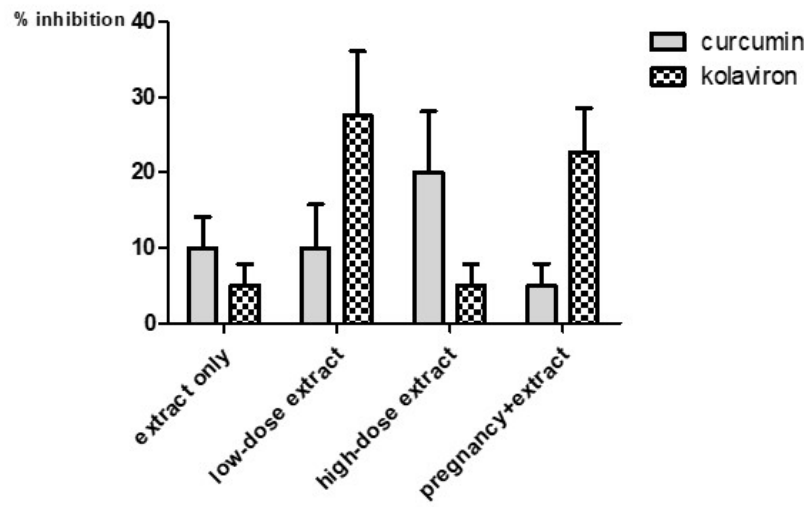

Fig. 1: Effect of extracts on SOD activity in the kidneys of female albino rats. Each bar represents mean \pm SEM of 6 rats.

This result shows no significant difference in the SOD activities of all the comparisons made. Rats treated with "curcumin only" however had a higher inhibition value $(10.00 \%)$ when compared with those treated with "kolaviron only" (5.00\%). Also, infertile rats treated with high-dose curcumin had a higher inhibition value (20.00 $\%)$ when compared with those treated with high-dose kolaviron (5.00\%). However, infertile rats treated with lowdose kolaviron had a higher inhibition value $(27.50 \%)$ when compared with those treated with low-dose curcumin $(10.00 \%)$. Also, pregnant rats treated with kolaviron had a higher inhibition value $(22.73 \%)$ when compared with the pregnant rats treated with curcumin $(4.32 \%)$.

The result in figure 2 shows data obtained for the SOD activities in the liver of all the groups treatment compared for the two extracts administered. 


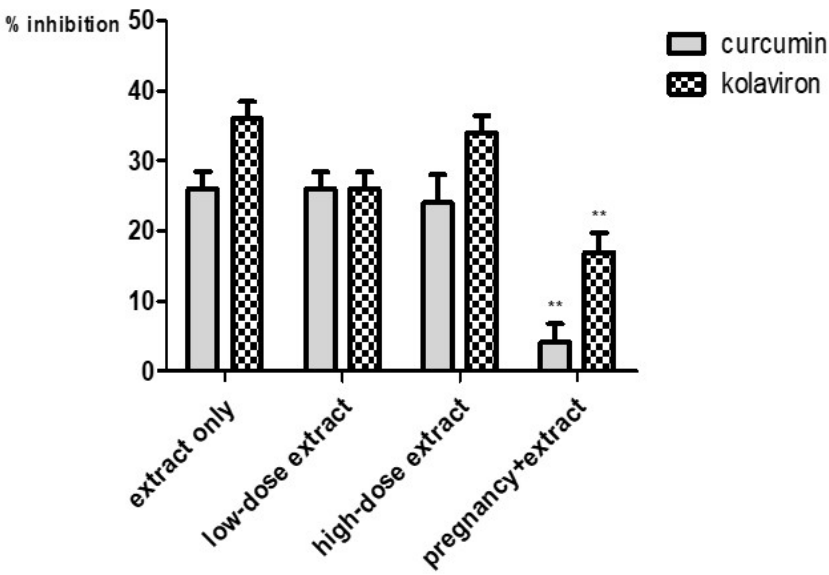

Fig. 2: Effect of extracts on SOD activity in the livers of female albino rats. Each bar represents mean \pm SEM of 6 rats. Mean bars having "**” in the same dosage differ significantly at $\mathrm{p}<0.01$.

This result shows that pregnant rats treated with kolaviron had a significantly higher inhibition value (16.97 $\%)$ when compared with pregnant rats treated with curcumin $(4.18 \%)$. There was however no significant difference in the remaining comparisons made in this result; although, rats treated with "kolaviron only" had a higher inhibition value $(36.00 \%)$ when compared with those treated with "curcumin only" $(26.00 \%)$. Also, infertile rats treated with high-dose kolaviron had a higher inhibition value $(34.00 \%)$ when compared with those treated with high-dose curcumin $(24.00 \%)$. Infertile rats treated with low-dose kolaviron had the same inhibition value $(26.00 \%)$ as those treated with low-dose curcumin.

The result in figure 3 shows data obtained for the SOD activities in the ovaries of all the groups treatment compared for the two extracts administered.

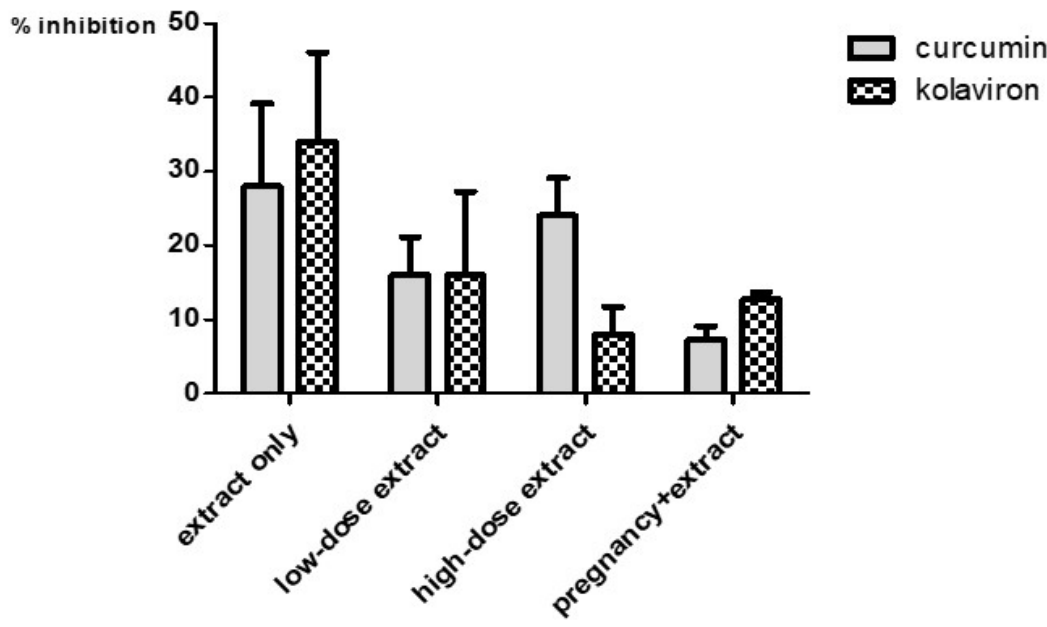

Fig. 3: Effect of extracts on SOD activity in the ovaries of female albino rats. Each bar represents mean $\pm \mathrm{SEM}$ of 6 rats.

This result shows no significant difference in the SOD activities of all the comparisons made. Rats treated with "kolaviron only" however had a higher inhibition value $(34.00 \%)$ when compared with those treated with "curcumin only" (28.00\%). Also, pregnant rats treated with kolaviron had a higher inhibition value $(12.73 \%)$ when compared with the pregnant rats treated with curcumin $(7.27 \%)$. However, infertile rats treated with high-dose curcumin had a higher inhibition value $(24.00 \%)$ when compared with those treated with high-dose kolaviron $(8.00$ $\%)$. Infertile rats treated with low-dose curcumin had the same inhibition value $(16.00 \%)$ as those treated with lowdose kolaviron.

The result in figure 4 shows data obtained for the GST activities in the kidney of all the groups treatment compared for the two extracts administered. 


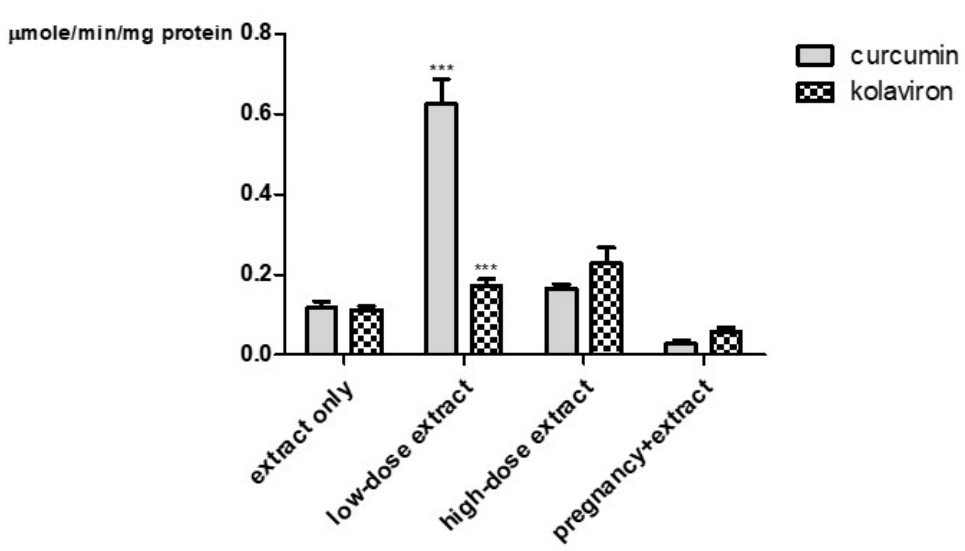

Fig. 4: Effect of extracts on GST activities in the kidneys of female albino rats. Mean bars having "***" in the same dosage differ significantly at $\mathrm{p}<0.001$.

This result shows that infertile rats treated with low-dose curcumin had a significantly higher value $(0.626$ $\mu \mathrm{mole} / \mathrm{min} / \mathrm{mg}$ protein) when compared with those treated with low-dose kolaviron $(0.1728 \mu \mathrm{mole} / \mathrm{min} / \mathrm{mg}$ protein). There was however no significant difference in the remaining comparisons made in this result; although, infertile rats treated with high-dose kolaviron had a higher value $(0.2295 \mu \mathrm{mole} / \mathrm{min} / \mathrm{mg}$ protein $)$ when compared with those treated with high-dose curcumin $(0.1653 \mu \mathrm{mole} / \mathrm{min} / \mathrm{mg}$ protein $)$. Also, pregnant rats treated with kolaviron had significantly higher value $(0.058 \mu \mathrm{mole} / \mathrm{min} / \mathrm{mg}$ protein $)$ when compared with those treated with curcumin $(0.028 \mu \mathrm{mole} / \mathrm{min} / \mathrm{mg}$ protein). Rats treated with "curcumin only" had a higher value $(0.118$ $\mu \mathrm{mole} / \mathrm{min} / \mathrm{mg}$ protein) when compared with those treated with "kolaviron only" $(0.1123 \mu \mathrm{mole} / \mathrm{min} / \mathrm{mg}$ protein $)$.

The result in figure 5 shows data obtained for the GST activities in the liver of all the groups treatment compared for the two extracts administered.

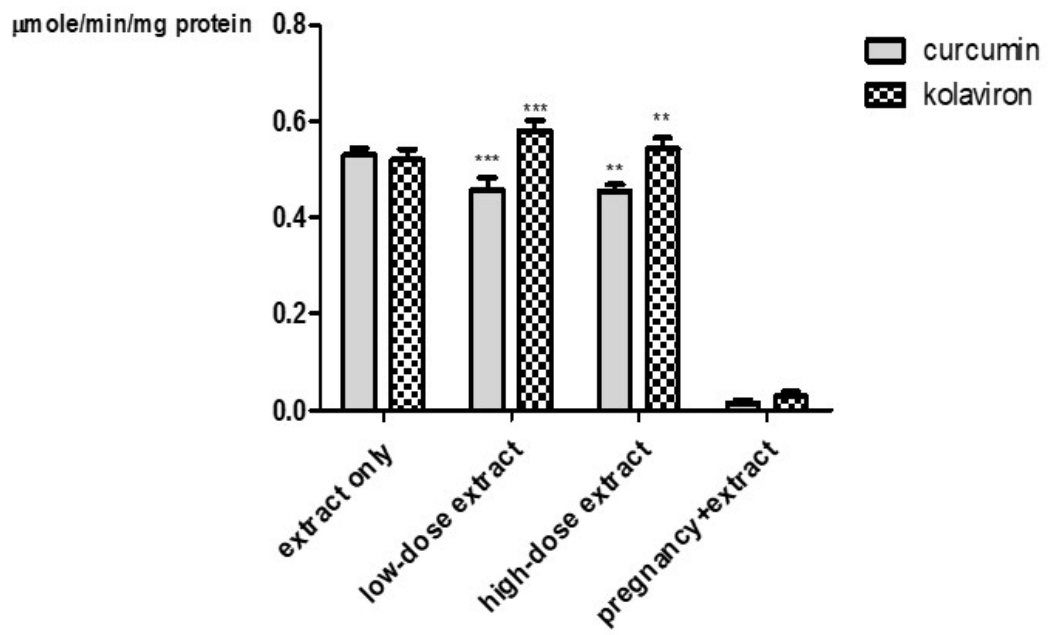

Fig. 5: Effect of extracts on GST activities in the livers of female albino rats. Each bar represents mean \pm SEM of 6 rats. Mean bars having "***" in the same dosage differ significantly at $\mathrm{p}<0.001$ while bars having "**" in the same dosage differ at $\mathrm{p}<0.01$.

This result shows that infertile rats treated with low-dose kolaviron had a significantly higher value $(0.5798$ $\mu \mathrm{mole} / \mathrm{min} / \mathrm{mg}$ protein) when compared with those treated with low-dose curcumin $(0.4568 \mu \mathrm{mole} / \mathrm{min} / \mathrm{mg}$ protein). Also, infertile rats treated with high-dose kolaviron had a significantly higher value $(0.5425$ $\mu \mathrm{mole} / \mathrm{min} / \mathrm{mg}$ protein) when compared with those treated with high-dose curcumin $(0.4544 \mu \mathrm{mole} / \mathrm{min} / \mathrm{mg}$ protein). There was no significant difference between pregnant rats treated with kolaviron $(0.029 \mu \mathrm{mole} / \mathrm{min} / \mathrm{mg}$ protein) when compared with those treated with curcumin $(0.0148 \mu \mathrm{mole} / \mathrm{min} / \mathrm{mg}$ protein $)$. Also, there was no significant difference between rats treated with curcumin $(0.5298 \mu \mathrm{mole} / \mathrm{min} / \mathrm{mg}$ protein $)$ when compared with those treated with kolaviron $(0.5194 \mu \mathrm{mole} / \mathrm{min} / \mathrm{mg}$ protein $)$.

The result in figure 6 shows data obtained for the GST activities in the ovaries of all the groups treatment compared for the two extracts administered. 


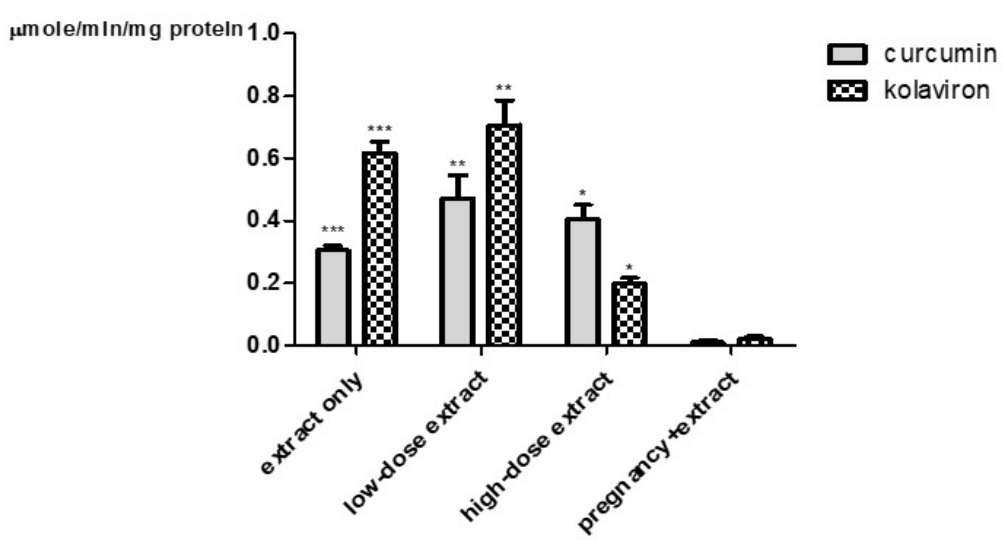

Fig. 6: Effect of extracts on GST activities in the ovaries of female albino rats. Each bar represents mean \pm SEM of 6 rats. Mean bars having "***" in the same dosage differ significantly at $p<0.001$ while bars having "**" in the same dosage differ at $\mathrm{p}<0.01$ and those having "**" differ significantly at $\mathrm{p}<0.05$.

This result shows that rats treated with "kolaviron only" had a significantly higher value $(0.6183$ $\mu \mathrm{mole} / \mathrm{min} / \mathrm{mg}$ protein) when compared with those treated with "curcumin only" $(0.3050 \mu \mathrm{mole} / \mathrm{min} / \mathrm{mg}$ protein $)$. Also, infertile rats treated with low-dose kolaviron had a significantly higher value $(0.7068 \mu \mathrm{mole} / \mathrm{min} / \mathrm{mg} \mathrm{protein})$ when compared with those treated with low-dose curcumin $(0.4723 \mu \mathrm{mole} / \mathrm{min} / \mathrm{mg}$ protein $)$. However, infertile rats treated with high-dose curcumin had a significantly higher value $(0.4048 \mu \mathrm{mole} / \mathrm{min} / \mathrm{mg}$ protein $)$ when compared with those treated with high-dose kolaviron $(0.199 \mu \mathrm{mole} / \mathrm{min} / \mathrm{mg}$ protein $)$. There was no significant difference between pregnant rats treated with kolaviron $(0.02025 \mu \mathrm{mole} / \mathrm{min} / \mathrm{mg}$ protein $)$ and those treated with curcumin $(0.0105 \mu \mathrm{mole} / \mathrm{min} / \mathrm{mg}$ protein $)$.

The result in figure 7 shows data obtained for the catalase activities in the kidneys of all the groups treatment compared for the two extracts administered.

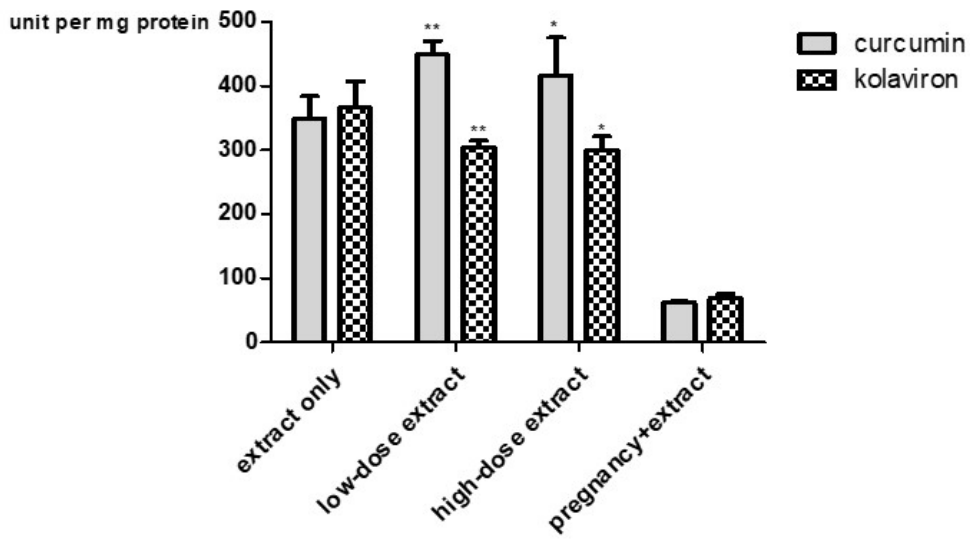

Fig. 7: Effect of extracts on catalase activities in the kidneys of female albino rats. Each bar represents mean \pm SEM of 6 rats. Mean bars having "**" in the same dosage differ at $\mathrm{p}<0.01$ while those having "*” differ significantly at $\mathrm{p}<0.05$.

This result shows that infertile rats treated with low-dose curcumin had significantly higher value (448.5 per $\mathrm{mg}$ protein) when compared with those treated with low-dose kolaviron (304.7 per mg protein). The result also shows that infertile rats treated with high-dose curcumin had significantly higher value (416.0 per mg protein) when compared with infertile rats treated with high-dose kolaviron (299.7 per mg protein). There was however no significant difference between the rats treated with "kolaviron only" (366.2 per mg protein) when compared to those treated with "curcumin only" (348.9 per mg protein). There was also no significant difference between the pregnant rats treated with kolaviron (69.13 per mg protein) and those treated with curcumin (62.29 per mg protein).

The result in figure 8 shows data obtained for the catalase activities in the liver of all the groups treatment compared for the two extracts administered. 


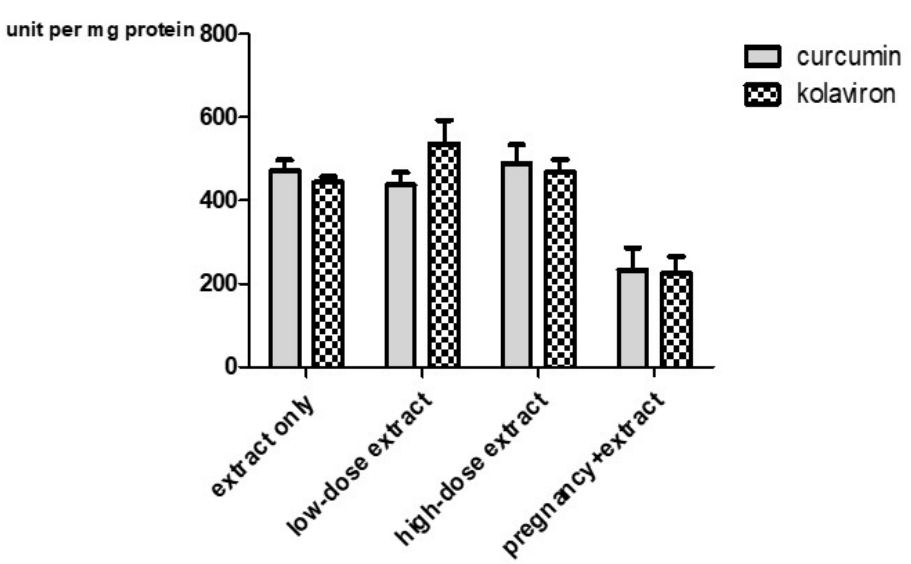

Fig. 8: Effect of extracts on catalase activities in the livers of female albino rats . Each bar represents mean $\pm \mathrm{SEM}$ of 6 rats. This result shows no significant difference in the catalase activities of all the comparisons made.

This result shows no significant difference in the catalase activities of all the comparisons made. However, rats treated with "curcumin only" had a higher value (471.5 per mg protein) when compared with rats treated with "kolaviron only" (443.7 per mg protein). Also, pregnant rats treated with curcumin had a higher value (233.1 per $\mathrm{mg}$ protein) when compared with those treated with kolaviron (225.6 per mg protein). Infertile rats treated with high-dose curcumin also had a higher value (488.7 per mg protein) when compared with those treated with highdose kolaviron (467.8 per mg protein). Infertile rats treated with low-dose kolaviron however had a higher value (536.2 per mg protein) when compared with those treated with low-dose curcumin (437.9 per mg protein).

The result in figure 9 shows data obtained for the catalase activities in the ovaries of all the groups treatment compared for the two extracts administered.

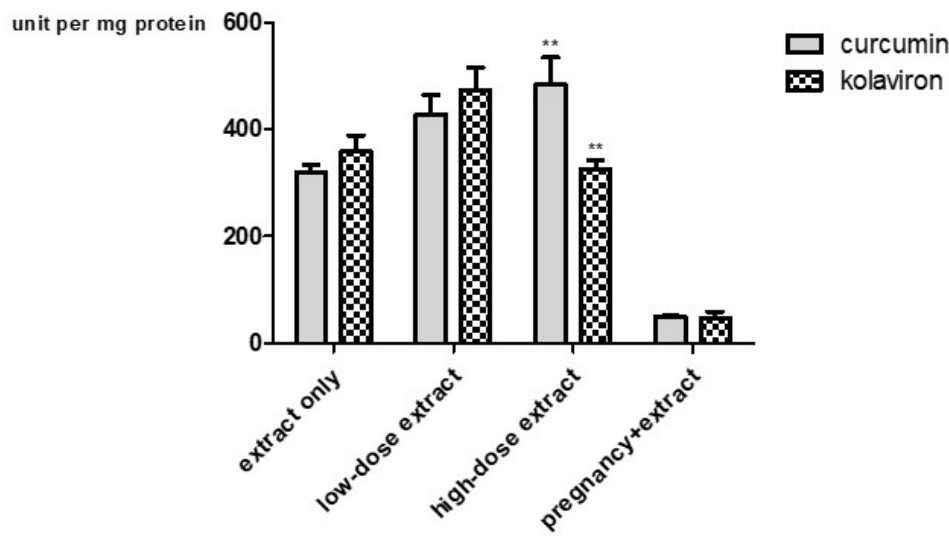

Fig. 9: Effect of extracts on catalase activities in the ovaries of female albino rats. Each bar represents mean \pm SEM of 6 rats. Mean bars having "**” in the same dosage differ at $\mathrm{p}<0.01$.

This result shows that infertile rats treated with high-dose curcumin had significantly higher value ( 484.0 per mg protein) when compared with those treated with high-dose kolaviron (325.3 per mg protein). There was however no significant difference in the remaining comparisons made in this result; although, infertile rats treated with low-dose kolaviron had a higher value (473.7 per mg protein) when compared with those of low-dose curcumin. Also, rats treated with "kolaviron only" had a higher value (359.1 per mg protein) when compared with those treated with "curcumin only" (320.0 per mg protein). Pregnant rats treated with curcumin also had a higher value (50.56 per mg protein) when compared with those treated with kolaviron (46.65 per mg protein).

\section{DISCUSSION AND CONCLUSION}

The findings from this study might as well be the first, in literature to compare the anti-oxidants properties of kolaviron and that of curcumin in any animal. This study showed that the groups treated with kolaviron generally had a higher increase in \% inhibition of superoxide in hepatocytes (with no significant difference) when compared with, especially the pregnant groups treated with kolaviron which was significantly higher than the pregnancy group treated with curcumin. This suggest that during pregnancy, kolaviron protects the liver cells better than curcumin, by preventing it from cell damage induced by superoxide as it causes many types of cell damage when not acted upon by dismutase (Hayyan et al., 2016; Desai and Bhilave, 2018). The result also suggests that kolaviron slows down lipid peroxidation more than curcumin in the ovaries by this comparisons made; most especially the 
ovaries of infertile rats treated with kolaviron. This could indicate that kolaviron generally slows down the rate of oxidation in the system than curcumin. This could also mean that kolaviron will ameliorate oxidative stress (particularly induced by lipid peroxidation) faster than curcumin. In the kidneys of the treated groups, infertile group treated with low-dose curcumin had a significantly higher concentration of GST than the infertile group treated with low-dose kolaviron; indicating that curcumin detoxifies kidney cells (in infertile women) better than kolaviron because glutathione S-transferases (GST) are best known for their ability to catalyze the conjugation of the reduced form of glutathione (GSH) to xenobiotic substrates for the purpose of detoxification and monitoring of cell injuries (Smith et al., 2013; Stoddard et al., 2019). In the livers of the infertile rats treated with the extracts (low-dose and high-dose), kolaviron increased the concentration of GSTs significantly when compared to curcumin at both doses, possibly indicating that kolaviron detoxifies the liver better than curcumin and could suggests that hepatocyte injury is better maintained by kolaviron. In the ovaries, this result indicate that kolaviron detoxifies the ovary of fertile rats better than with curcumin, it also indicates that ovarian cell injuries are better ameliorated with kolaviron. This study also suggests that infertile rats treated with low-dose kolaviron had their ovaries better detoxified than infertile rats treated with low-dose curcumin, although the reverse was the case when treated with high-dose of the extracts.

Furthermore, the result also indicates that curcumin might protects the kidney cells of infertile rats from oxidative damage better than kolaviron; as concentrations of catalase in infertile rats treated with curcumin were significantly higher than those treated with kolaviron, Since Catalase detoxifies hydrogen peroxide $\left(\mathrm{H}_{2} \mathrm{O}_{2}\right)$ into oxygen and water, (Thimraj et al., 2018), when $\mathrm{H}_{2} \mathrm{O}_{2}$ is present in high concentrations (Cao et al., 2003; Day, 2009, Cho et al., 2019); this makes it a very important enzyme in protecting the cell from oxidative damage induced by reactive oxygen species (ROS). In the ovaries of infertile rats treated with high-dose of the extracts, the obtained result indicates that curcumin protects the ovarian cells from oxidative damage better than kolaviron.

In conclusion, this result indicates that kolaviron protects the liver and ovary more than curcumin which exhibits more protection of the kidney, hence kolaviron prevents oxidative stress better in the ovaries and livers of females while curcumin prevents oxidative stress better in the kidneys of females. It should also be noted that long term moderate oxidative stress has been linked to infertility, (Shi et al., 2016; Bisht et al., 2017), hence this study shows that kolaviron could assist to prevent this and could be useful therapeutically in the prevention of infertility caused by oxidative stress.

\section{REFERENCE}

Ammon, H. P. T., \& Wahl, M. A. (1991). Pharmacology of Curcuma longa. Planta Med, 57(01), 1-7. doi: $10.1055 / \mathrm{s}-2006-960004$

Bisht, S., Faiq, M., Tolahunase, M., \& Dada, R. (2017). Oxidative stress and male infertility. Nature Reviews Urology, 14(8), 470.

Cao, C., Leng, Y., \& Kufe, D. (2003). Catalase Activity Is Regulated by c-Abl and Arg in the Oxidative Stress Response. Journal of Biological Chemistry, 278(32), 29667-29675. doi: 10.1074/jbc.M301292200

Cho, O., Kim, H.-S., Park, K.-Y., \& Heo, T.-H. (2019). A Comparison of the Anti-Inflammatory Effects of Four Combined Statin and Antiplatelet Therapies on Tumor Necrosis Factor-Mediated Acute Inflammation in vivo. Pharmacology, 104(1-2), 21-27.

Day, B. J. (2009). Catalase and glutathione peroxidase mimics. Biochemical Pharmacology, 77(3), 285-296. doi: https://doi.org/10.1016/j.bcp.2008.09.029

Desai, T., \& Bhilave, M. (2018). Toxicological studies of methanol on superoxide dismutase (SOD) activity of freshwater fish Cirrhinus mrigala, Journal of Materials Chemistry B, 7(33), 5019-5037.

Farombi, E. O., Adedara, I. A., Ajayi, B. O., Ayepola, O. R., \& Egbeme, E. E. (2013). Kolaviron, a natural antioxidant and anti - inflammatory phytochemical prevents dextran sulphate sodium - induced colitis in rats. Basic \& clinical pharmacology \& toxicology, 113(1), 49-55.

Farombi, E. O., Akanni, O. O., \& Emerole, G. O. (2002). Antioxidant and scavenging activities of flavonoid extract (kolaviron) of Garcinia kola seeds. Pharmaceutical Biology, 40(2), 107-116.

Hayyan, M., Hashim, M. A., \& AlNashef, I. M. (2016). Superoxide Ion: Generation and Chemical Implications. Chemical Reviews, 116(5), 3029-3085. doi: 10.1021/acs.chemrev.5b00407

Hernandez-Reif, M., Horton, C., Vaughn, J. I., Pollard, A., Juarez, E., Kendrick, A., \& Burns-Nader, S. (2019). The use of complementary and alternative medicine by adults and children in the south. Journal of Community Engagement and Scholarship, 8(2), 7.

José Gutiérrez-Salinas ,1 Liliana García-Ortíz,2 José A. Morales González,3 Sergio Hernández-Rodríguez,1 Sotero Ramírez-García,4 Norma R. Núñez-Ramos,4 and Eduardo Madrigal-Santillán3 (2013), In Vitro Effect of Sodium Fluoride on Malondialdehyde Concentration and on Superoxide Dismutase, Catalase, and Glutathione Peroxidase in Human Erythrocytes, Volume 13 |Article ID 864718 | 7 pages | https://doi.org/10.1155/2013/864718 
Odewabi, A. O., O. A. Ogundahunsi, M. O. Oyalowo, (2014), Effect of Exposure to Petroleum Fumes on Plasma Antioxidant Defense System in Petrol Attendants BJPT.5. 5461. DOI:10.19026/Corpus ID: 42569340

Owaga.,E.E., A Elbakkoush, MS KS, R Lupia, (2014), Antiallergic effects of probiotic lactobacilli-cellular and molecular mechanisms Journal of Microbiology Research 2014, 4(2): 92-97.

Pérez-Montaño F., C Alías-Villegas 1, R A Bellogín 1, P del Cerro 1, M R Espuny 1, I Jiménez-Guerrero 1, F J López-Baena 1, F J Ollero 1, T Cubo 2, (2013), Plant growth promotion in cereal and leguminous agricultural important plants: from microorganism capacities to crop production. Microbiol Res. May-Jun 2014;169(56):325-36. doi: 10.1016/j.micres..09.011. Epub 2013 Sep 27.

Priyadarsini K.I. (2014), The Chemistry of Curcumin: From Extraction to Therapeutic Agent, Molecules, 19(12), 20091-20112; https://doi.org/10.3390/molecules191220091

Shi, L., Zhang, J., Lai, Z., Tian, Y., Fang, L., Wu, M., . . Wang, S. (2016). Long-term moderate oxidative stress decreased ovarian reproductive function by reducing follicle quality and progesterone production. PLoS One, 11(9), e0162194.

Smith, G. S., Walter, G. L., \& Walker, R. M. (2013). Chapter 18 - Clinical Pathology in Non-Clinical Toxicology Testing. In W. M. Haschek, C. G. Rousseaux \& M. A. Wallig (Eds.), Haschek and Rousseaux's Handbook of Toxicologic Pathology (Third Edition) (pp. 565-594). Boston: Academic Press.

Srivastava, et al., (2016), Phytochemical screening and in vitro antioxidant potential of methanolic extract of Epipremnum aureum (Linden and Andre) International Journal of Pharmaceutical Research \& Allied Sciences, , 5(2):1-6.

Stoddard, E. G., Killinger, B. J., Nag, S. A., Martin, J., Corley, R., Smith, J. N., \& Wright, A. T. (2019). Benzo [a] pyrene Induction of Glutathione S-transferases: An activity-based protein profiling investigation. Chemical research in toxicology, 32(6), 1259-1267.

Stohs, S., and Ray, S. (2019). Issues with human bioavailability determinations of bioactive curcumin. Biomed $J$ Sci Tech Res, 10.

Thimraj, T. A., George, L., Asrafuzzaman, S., Upadhyay, S., \& Ganguly, K. (2018). Chapter 7 - Oxidative Signaling in Chronic Obstructive Airway Diseases. In S. Chatterjee, W. Jungraithmayr \& D. Bagchi (Eds.), Immunity and Inflammation in Health and Disease (pp. 79-98): Academic Press. 